DOI 10.18551/rjoas.2019-05.01

\title{
ORGANIZATIONAL RESTRUCTURING OF MANADO CITY GOVERNMENT
}

\author{
Tarore Steven Vleike \\ Doctoral Program of Public Administration, Faculty of Administrative Science, \\ University of Brawijaya, Indonesia
}

Gani Abdul Juli Andi, Mardiyono, Pratiwi Ratih Nur

Faculty of Administrative Science, University of Brawijaya, Indonesia

*E-mail: stevenvtarore@gmail.com

\begin{abstract}
Organizations or institutions are basically tools or means of acting to achieve a common goal. Because as a tool, then when there is a change in the goals to be achieved, the organization must adjust to the demands of the change. The form of adaptation of an organization or institution can be done with an institutional development approach through organizational restructuring that is adaptive to these changes. This study offers an overview and analysis of the restructuring process carried out on Manado City Government so that it can create an effective and efficient organization in presenting public services. By using a qualitative approach, this research is intended to find out the need for restructuring in Manado City Government. The results of the study show that, if the restructuring of public organizations is initiated to improve public services, the approach of poor structure and rich functions in the structure of public organizations will improve the performance and work productivity of public organizations. In addition, the regional government organizations is an answer to any changes, is a complex strategy, aimed at changing the beliefs, attitudes, values and organizational structures in order to have the ability to advance knowledge of technology, markets and new challenges.
\end{abstract}

\section{KEY WORDS}

Restructuring, public organization, public service, organizational change.

The long process of reforming the government system in Indonesia, led to changes in the system of government, which was initially a centralized government system become a decentralized government system. This change is related to aspects of philosophy, the theory and principles of governance to be achieved. This change also gives an opportunity for regions to regulate their own households widely and responsibly, known as regional autonomy. This regional autonomy was held based on Law No. 22/ 1999 about Regional Government, which was subsequently revised with the emergence of Law No. 32/ 2004 and Law No. 12/ 2008 about Second Amendment to Republic of Indonesia Law No. 32/ 2004 concerning Government Region, as well as Law No. 23/ 2014 concerning Regional Government.

From the construction of Articles 18, 18A and 18B in Chapter VI of the 1945 Constitution, Law No. 32/ 2004 and Law No. 23/ 2014 concerning Regional Government has a purpose, where the granting of regional autonomy is to increase welfare, equitable development and the results and to increase the utilization of the regional potential optimally and integrated in order to increase people's welfare; promoting the initiative and active participation of the community in the implementation of regional autonomy widely, real and responsibly, as well as strengthening national unity and integrity, improving public services and regional competitiveness. Regional autonomy as a form of implementation of the principle of decentralization in administering government which implemented by the government is the answer to the demands of the community. The regional government can implement its function to regulate and manage regional authority based on the interests of the local community so that the implementation of the functions of the government can be 
implemented properly, then the regional government needs an effective and efficient regional apparatus organization or Regional Work Unit (Satuan Kerja Perangkat Daerah/SKPD) as an element or part of the bureaucracy. The appearance of a large bureaucracy will have an impact on consuming a lot of regional resources, there is no uniformity, and this phenomenon has been widely seen in the practice of bureaucracy both at the central and regional levels. This should be adjusted to regional needs and community needs, so that organizational restructuring is needed.

Restructuring is implemented to prepare and reorganize all organizational resources and direct them to achieve a high level of competitiveness in a dynamic and competitive environment (Köper and Richter, 2014). Organizational restructuring in improving organizational performance in Manado city government has not yet thoroughly touched on improving the organizational structure of the regional apparatus. If the restructuring is implemented in accordance with local interests and the aspirations of the community, an ideal regional organizational structure will be formed in accordance with local conditions which can ultimately improve organizational performance. In implementing restructuring, the regional government is faced with the problem of rearranging the organizational structure, the amount of costs incurred in the preparation of new structures in accordance with the new regulations. This is in line with Gani (2013), that the derivisation regulations that have been established then the Regional Apparatus must arrange programs that become the elaboration of the vision and mission of the Regional Government in accordance with their respective main tasks and functions and compile the Accountability Performance of Government Agencies, Restructuring is implemented by downsizing and rightsizing, namely Downsizing echelon IVa, Office Merger, Office Merger, Body Formation, and Office Formation.

Based on the observations of the researchers, the reason for the restructuring needed in the Manado City Government is to optimize the bureaucracy that is too large and the resources of apparatus that are less professional, provide an alternative solution to the complexity of problems in the city of Manado and conduct organizational restructuring to improve performance. From the description of the phenomena that have been explained, restructuring is implemented so that organizations survive in the face of turbulent and uncertain environmental changes (Daft, 1992), this paper emphasizes several research issues that focus on the formulation of problems regarding the need to restructure the organization, factors that influence the restructuring and restructuring model that are effective in improving the performance of Manado City Government organization.

\section{LITERATURE REVIEW}

Organizational restructuring in a very narrow sense includes aspects of organizational performance, operational cooperation, work systems and procedures and delegation of authority and autonomy. While organizational restructuring in a broad sense, covers all aspects of the company that greatly affect the productivity of the company, which includes human resources, financial resources, and other resources including facilities and infrastructure. The concept of restructuring according to Gouillart and Kelly (1995) is part of an organizational transformation called The Four R's Transformation (Reimagine, Reform, Resist and Recreate).

Associated with the development of management science as stated by Savage (1996), demands for restructuring can be said to be the embodiment of the fifth generation of management, namely management based on dynamic teamming, knowledge networking, cross border or out of board, and virtual enterprises. All of that leads to an agreement that managing the organization in modern times like today is no longer possible to rely solely on conventional techniques such as mechanistic structures and convoluted command lines. On the contrary, organizations must be treated flexibly, enlarging delegation of authority, spurring the roles and responsibilities of functional staff, and having a spend on control that is not too long. In implementing the restructuring policy according to Ibrahim (2018) states 
that the approach used in organizational restructuring policies is the system dynamics method.

Constraints faced in restructuring come from internal \& external organizations. The impact of internal \& external changes that are difficult to anticipate, in time will bring the organization to a critical point that does not show optimal performance and is unable to provide quality services as expected by the community. For this reason, a region needs to grow new energy by restructuring so that the region can continue in advance and survive in the future.

In this connection, according to Mintzberg (1979) there are five main parts forming the structure, including: The operating core, The strategic apex, The Middle line, Technodtructure, The support staff. Mintzberg's theory of organizational structure can be seen in figure 1 below:

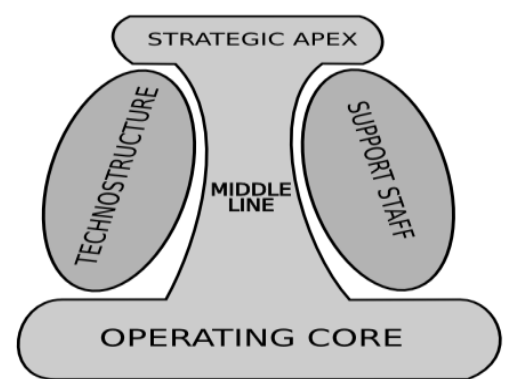

Figure 1 - Main Structure Forming Sections (Source: Mintzberg, 1979)

Noting the figure above, Mintzberg (1979) describes each of the following five organizational parts:

- The Strategic Apec. Is the top level manager, who is given overall responsibility for the organization (called the president, supervisor, or etc), and several other top level managers who pay attention to global matters, including those who provide direct support to top managers, namely secretaries, assistants and so on. The strategic apex is responsible for ensuring an organization carries out its mission and fulfills the needs of the people who control or against people who have no power over the organization (owners, government agencies, employee unions, pressure groups). Regarding the size of the organization with this coordination mechanism, it depends on the managers of strategic Apex and the middle line that influence;

- The Middle Line. The managers are the liaison between the operating core and strategic apex. This chain runs from the senior manager under the strategic apex to the first line supervisor, who has direct authority over the operating core, and forms a coordination mechanism called direct supervision;

- Technostructur. Analysts who have the responsibility to implement certain forms of standardization in the organization. These analysts come from the workflow of operations that design, plan, change, or train the people who do it, but they don't do it themselves. Thus technostructure is effective only when it can use analytical techniques to make other people's work more effective;

- The Support Staff. It is people who fill the staff unit, which provides indirect support services to the organization. Support staff are most often included together with technostructure and given authority as staff who advise the management. But these support staff are empirically different from the technostructure, they do not pay attention to standardization and cannot impose the advice given (although they might do some things too);

- The Operating Core. It is employees who carry out basic work that produces products and services, who called as an operator. The operator performs four main functions, namely: (1) getting input for production; (2) transforming input into output. Some organizations transform material by turning into finished goods, while others transform individual parts together into complete units; (3) distribute output, for 
example by selling and physically recording what goes into the transformation process; (4) provide direct support to input, process and output functions, for example by carrying out maintenance of machine operations and raw material inventory. The operating core is a protected part of the organization, by standardizing.

According to Bennis and Mische (1995), leadership is included in the main element of restructuring. Effective and visible leadership, means that leaders who carry out restructuring must have a number of skills and abilities such as creativity, an influential vision, in-depth knowledge of the business in the company, and good character and careful consideration. Bennis and Mische (1995) propose five steps of restructuring, namely: The first step is to create a vision and set goals, step two, strive for benchmarking and define success. The third step is to innovate the process, the fourth step is transforming the organization, the fifth step is monitoring the restructured process.

To be able to achieve the expected synergy, the reengineering process is pursued through four steps, namely: 1) Determining the desired needs and or goals; 2) Making a plan; 3) Implementation of the plan; 4) Program monitoring (Obolensky, 1996). Each stage, restructuring has different goals, targets, tasks and final results. In each stage there is a process group, which is a combination of work steps, individual tasks, work results and formal delivery. Each work step can be expanded, deleted or adjusted to meet the unit requirements of the organization and the overall restructuring project.

Changes and processes of change are usually carried out by people through a focus on organizational change. Organizations that can make changes include public companies, in government bodies, charities or other types of institutions. According to Potts and LaMarsh (2004) that "Change is a shift from the present state of an organization to a desired condition in the future". The change from the present situation is seen from the point of view of structure, process of people and culture. Brooten (1978) states that change is a process that causes changes in individual or institutional behavior patterns (Wibowo, 2008). namely:

There are four models of approaches in management change (Davidson, 2007),

- Rational Approach - Empirical. The approach that will be taken uses rational and empirical considerations. It is assumed that the changed target will accept changes when accepting consideration to change. There needs to be good and effective communication regarding incentives or results that will benefit them if the change is successful. They will make changes not because they are forced, afraid or go along without being involved and apathetic;

- Normative Approach - Re-educative. The approach used is to provide re-education regarding the values and norms of the need for change. People will change because of a need. It takes a long time to make changes;

- Power Approach - Coercive. This approach is basically compliance, so it uses the leadership. This approach is effective if the employee recognizes the expertise and validity of the party exercising power. Need leaders who are firm, fair and able to protect subordinates;

- Environmental Approach - Adaptive. The basic approach to the environment is the ability to adapt to the latest environment or situation.

In essence human life and organization are covered by continuous change. On the one hand because of the existence of external factors that encourage change, on the other hand, change is actually felt as an external need. Therefore, change needs to be understood to reduce the pressure of resistance to change. Resistance is natural and can be overcome.

Improved organizational performance can be determined by measuring the performance of the organization. This is needed in the application of management concepts to measure the effectiveness and efficiency of managing all organizational resources in achieving goals. Organizations can achieve good performance if all organizational unit activities work integratively based on mutually agreed vision and mission. In the government field, the importance of the organization's vision and mission is also needed, as stated by Osborne and Gaebler regarding the superiority of government driven by mission (Osborne and Gaebler, 1995). 
Governments that have entrepreneurial spirit prioritize the realization of vision (goals) and mission (goals), because in this way the administration of government will be more efficient, effective, innovative, flexible, and the workers will have a higher enthusiasm to realize their goals. This high spirit can be realized because the vision and mission of the organization have been clearly defined, then the implementation is handed over / delegated to organizational units with clear work procedures, and supported by the availability of adequate funds and employees (Osborne and Gaebler, 1995).

As part of the Government Agency Performance Accountability System, performance measurement plays a very important role. Performance accountability of government agencies cannot be accounted for if it is not equipped with information about the results that have been obtained. While the results obtained by each government agency, its performance must be measured to the extent of its achievement through performance measurement (Sudirman \& Widjanarko, 2004).

James B Whittaker (in Sudirman \& Widjanarko, 2004) defines Performance Measurement as a management tool used to improve the quality of decision making and accountability. Furthermore, it is said that performance management as a strategic process is used to assess the achievement of the organization's strategic goals and objectives. According to Whittaker, a key element of the performance measurement system consists of:

(1) Planning and Setting Objectives;

(2) Relevant Size Development;

(3) Formal reporting of results;

(4) Use of information.

Performance measurement is not intended to act as a mechanism to give reward / punishment, but performance measurement serves as a communication tool and management tool to improve organizational performance. Performance measurement in government is not a new activity. Each department, work unit and task implementation unit has been programmed to deliver information in the form of periodic reports (quarterly / semester / yearly) for the implementation of their main tasks and functions.

\section{METHODS OF RESEARCH}

This study includes qualitative research with a basic naturalistic principle with the object of the Manado City Government Organizational Restructuring research with the consideration that the Manado City Government has made a relatively large government organizational structure change as a consequence of the implementation of regional autonomy based on Law No. 32/ 2004 concerning Regional Government and Regulations Government No. 41/ 2007 concerning Regional Device Organization Guidelines, Government Regulation No. 38/ 2007 concerning Division of Government Affairs, Provincial Government, and Regency / City Regional Government, and Minister of Home Affairs Regulation No. 57/ 2007 concerning Technical Guidelines for Structuring Regional Device Organizations. This is one of the requirements desired by a study of organizational restructuring in improving organizational performance in Manado City Government.

Through a qualitative approach, researchers are expected to be able to fully and comprehensively describe the phenomenon under study as described in the focus of the study, so that in the end it can answer the problems formulated and underlie the use of qualitative approaches (Miles \& Huberman, 2014). The informants in this study were the Policy Formulator (Mayor); Regional Secretary; Assistant 1,2,3; Bureaucrats; Regional House of Representatives Members; Regional Government Observer, Academician; Community leaders, NGO leaders, media groups and other external groups and staff at the Restructuring Policy Formulation Institution who were involved. Procedures and data collection techniques, the writer make observations, in-depth interviews and documentation. Furthermore, in measuring the validity and analysis of data in this qualitative study, researchers used interactive models from Miles, Huberman and Saldana (2014), namely data collection, data reduction, data presentation and subsequent conclusions. 


\section{RESULTS AND DISCUSSION}

Manado City Government Organization Restructuring Process. The Manado City Government organization restructuring process, which begins with an understanding of its mandate and mission as a public organization, examines its organizational environment, and changes organizational structure by adding new organizational units within the framework of improving public service performance is a strategic process for Manado City Government in maintaining the effectiveness of existence and its function as a public organization. However, the quality of apparatus resources, laws and regulations, public desires, and fostering economic resource management, are factors that influence organizational restructuring in improving the performance of public organizations (Suyono, 2002).

As is known, that public organizations or institutions such as Manado City Government are basically tools or means of acting for the state or government to carry out their duties, namely to improve the welfare of the community through the provision of public services. As a tool to achieve goals, the existence of Manado City Government organization must always refer to the mandate that must be carried out, the mission that must be actualized, and adaptive to face the environmental changes. Therefore, the restructuring that took place in Manado City Government organization must be well planned if it wants a change in the performance of its organization in a better direction. Mandates are demands, norms, rules, directives, mandates, as well as formal and informal tasks that will be carried out by the organization. Before an organization can define its mission and values, it must be clearly known what needs to be done and not done by external authorities. This requirement may be codified in law, constitution, articles about organization, or charter (Bryson, 1988).

The importance of understanding the mandate and mission of the organization in restructuring regional / municipal government organizations, also emphasized by the Apparatus Bureau (2008) that institutional arrangements, organizations are based on clear vision, mission and strategy. With a clear vision and mission, an organization that is truly in accordance with the demands of needs can be prepared, especially able to balance the ability of the organization's resources with the real needs of the community and the operations set out in the strategic plan.

Minor Proposition 1 "If the process of restructuring public organizations does not begin with an understanding of the mandate and mission of the organization, organizational restructuring will have an impact on the weak work productivity of the organization".

Analysis of the environmental conditions of the organization is also important in the process of restructuring public organizations, such as Manado City Government, both the internal and external environment of the organization. Internal environment is a factor that shows the situation and conditions experienced or that occur within an organization. Analysis of internal environmental factors is intended to identify strengths and weaknesses of an organization. According to Higgins (Salusu, 1996), strength is a situation and internal capabilities that are positive, which allows the organization to have a strategic advantage in achieving its goals, while weakness is a situation and internal incompetence which results in the organization unable to achieve its goals. These two internal factors influence each other. If the weakness is very dominant, then there is a possibility that the strength of the organization will turn out to be a weakness. Conversely, existing strengths can be used to improve or overcome a weakness. Manado City Government organization restructuring policy has still revolved around the addition and elimination of organizational structure aspects. As a public organization, Manado City Government is a state tool to serve the public interest without being oriented to profit seeking. Therefore, along with the demand for more effective services and efficiency from the public, the existence of public organizations must be adaptive, creative, and innovative. This means that the institutional development of public organizations is a demand. The form of self-adjustment of an organization or institution can be done with an institutional development or restructuring approach.

Minor Proposition 2 "If the restructuring process of a local government organization does not begin with an understanding of the organizational structure, then the restructuring 
of regional government organizations will not have an impact on increasing the work productivity of the organization".

In order to respond and implement the granting of regional autonomy, the restructuring of regional government organizations must be based on considerations which include achieving poor structure but rich in functions towards the efficiency of the performance of the regional apparatus themselves, absorption of all personnel in the organizational structure so that the success and avoidance of termination of employment, increases the responsibility of regional governments that have implications for improving regional performance (Supriyono, 2007). Based on the results of a discussion on the Development of Manado City Government Organizational Functions, the minor propositions can be formulated as follows:

Minor Proposition 3 "If the process of restructuring local government organizations does not begin with an understanding of the development of organizational functions, the process of restructuring local government organizations is less supportive of the main tasks and functions of the organization".

Supporting Factors and Restructuring Obstacles in Manado City Government. The quantity and quality of human resources (State Civil Apparatus/ASN) in Manado city government are still considered to be less supportive in achieving the objectives of Organizational Restructuring in Manado City Government. In the context of human resources, after the restructuring process, it is necessary to transfer another employee to another Regional Work Unit whose duties and authority are transferred. The willingness of the Regional Head to make changes to the organizational structure of Manado City Government, both by adding and removing organizational units and the attitude of approval and rejection of some officials within Manado City Government organization are factors that are supporting and inhibiting the restructuring of regional government organizations. Organizational member support for organizational restructuring usually occurs when organizational restructuring policies provide opportunities for new positions to emerge within the organization. But the opposite attitude, namely the rejection of organizational members will occur if the restructuring policy threatens the loss of position or position of members of the organization. Therefore, in the restructuring of regional government organizations, the existence of human resources is a variable that can affect change in public service organizations (Landau, 1993).

So basically the purpose of reforms in regional government institutions is not just an action to make regional government institutions fatter in order to accommodate office interests or to be leaner in order to reduce the burden of costs borne by the region. However, institutional reform of the regional government must be an act of change or renewal that has dimensions of restructuring, revitalization and re-functionalization in order to form a regional government that can truly meet the demands of community needs, such as faster, cheaper and better quality services. (Sedarmayanti, 2009).

Whereas for the foreseeable future the rearrangement of institutions cannot be avoided, in order to achieve clear division of authority and responsibility between existing organizational units in realizing the five functions of regional government institutions, namely strategic functions apec, middle line, technostructure, support staff, and operating core, the level of local governance must emphasize the values of freedom / independence, participation, democracy, accountability and efficiency (Sumartono et al., 2001). Based on a discussion of the supporting factors and obstacles to the restructuring of Manado City Government organization, the minor propositions can be formulated as follows:

Minor Proposition 4 "If the organization's restructuring process is not supported by human resources (State Civil Apparatus), the political will of the regional head and appropriate central government policies, then organizational restructuring is less supportive in enhancing the effectiveness of regional apparatus organizations".

Organizational Restructuring Model to Improve Performance. The restructuring of Manado City Government organization carried out by adding organizational units is a phenomenon that is often carried out by Regional Heads in the era of regional autonomy. However, the development of regional government organizations that focus on increasing the number of organizational units is not based on the desire to improve the effectiveness and 
efficiency of the performance of regional government organizations, but rather to facilitate positions from members of organizations that end up increasing the budget.

The decentralization policy that has provided greater space for local governments to regulate and manage their own households must be utilized properly in order to improve services for the welfare of the community. The emergence of various consequences due to the decentralization policy and the occurrence of various changes in the lives of people in the regions, demands the existence of a reform movement in the institutions of regional government in order to be able to respond to the dynamics and real needs of citizens. Regional government institutional reforms must be directed to reforms that have dimensions of restructuring, revitalization, and refunctionalization through integrated approaches to aspects of culture, structure, management, human resources, and the leadership of the regional government in order to become a more efficient, effective, adaptive, accountable, and better organization in providing services to the community, so that creating community welfare as mandated by the decentralization or regional autonomy policy. In the public administration system as a system of working together groups of people to achieve common goals (Pfiffner and Presthus, 1960), the existence of the Regional Government as a public organization is an important element as a place for public officials to carry out the mandate of public services.

The ability of regional government organizations to carry out their functions (Supriyono, 2007) depends on three dimensions of institutional development. First, the effectiveness of regional government institutions in carrying out the functions of planning and implementation. Second, the direction of changing the role of local government institutions in addressing decentralization policies. Third, institutionalization in regional government institutions and other objectives to solve institutional effectiveness problems, the direction of changes in the role of institutions, and the problem of institutionalization in regional government institutions. In local government organizations, efforts to create organizational effectiveness through restructuring in the form of rationalization of employees are not popular and appropriate policies. This is different from private organizations, organizational restructuring in the form of reducing the number of employees (downsizing) is actually a general measure in maintaining the effectiveness of the organization (Basiran, Kusuma \& Paselle, 2018). Based on a discussion of Manado City Government organization restructuring model, the minor propositions can be formulated as follows:

Minor Proposition 5 "If the restructuring process of the Regional Government organization does not consider organizational management (standard operation procedure organization), then the restructuring of the organization of the device is limited to the central government policy nomenclature".

Furthermore, considering the five minor propositions mentioned above, a major proposition can be formulated regarding the restructuring of public organizations in improving public service performance as follows:

Major Proposition "The restructuring of regional government organizations is an answer to any changes, is a complex strategy, aimed at changing the beliefs, attitudes, values and organizational structures in order to have the ability to advance knowledge of technology, markets and new challenges".

\section{CONCLUSION}

The restructuring process for Manado City Government was carried out based on Central Government policies, begins with an understanding of the organization's mandate and mission as a public organization. The restructuring is intended to realize Manado City Government organization that is effective and efficient in presenting public services. In rearranging Government Organizations. The city of Manado is oriented to meet the provisions of Government Regulation No. 41/ 2007 and future regional interests. For this reason, Manado City Government Organization increases the number of bodies in its structure. 
In restructuring, there are factors that influence such as the quality and quantity of Human Resources (State Civil Apparatus/ASN) which are still lacking so that they do not support the objectives of Organizational Restructuring, the number of State Civil Apparatus in Manado City Government has drastically reduced (retirement, transfer and death); the operational expenditure budget before and after the Organizational Restructuring of Manado City Government did not experience significant changes; Political will of the Regional Head where power can also influence the design of organizational policy formulations namely on the basis of the formation of organizational units, because the policy formulation process is often influenced by the power of the leader as the policy holder that influences the results of the policies to be made and the changes in the Central Government Policy which are the main factors or factors that most influence the restructuring of Manado City Government organization.

The recommendations in this study are: First, the restructuring of regional government organizations as public organizations must be aimed at improving good governance. However, the restructuring of regional government organizations must be carried out consciously and planned; Secondly, the restructuring of the organization is an organizational response that is automatic towards fluctuations or changes in environmental conditions of the organization; Third, restructuring is intended to make public bureaucracy more economical, more productive, more efficient, more effective, more adaptive, more innovative, more accountable and better at serving the public; Fourth, the restructuring of Regional Government organizations based on a poor approach and rich functions in the context of public services, will increase effectiveness and efficiency in the performance of regional government organizations as public organizations; Fifth, the restructuring of public organizations is initiated to improve public services, so the approach to poor structure and rich functions in the structure of public organizations will improve the performance and work productivity of public organizations.

\section{REFERENCES}

1. Basiran., Kusuma, A.R., \& Paselle, E. (2018). Restrukturisasi Organisasi Perangkat Daerah Provinsi Kalimantan Utara. eJournal Administrative Reform, 2018, 6 (4):403-412. ISSN 2338-7637.

2. Bennis, W. and Mische, M. (1995). 21st Century Organization: The Reinventing Through Reengineering. Information Systems Management, 13 (3): 58-65.

3. Bryson, J.M. (1988). A strategic Planning Procces for Public and Non-profit Organization. Long Range Planning, 21 (1):73-81.

4. Davidson, J. (2007). The complete Ideal's guide Management. Jakarta: Pranada Media.

5. Daft, R.L. (1992). Organization Theory and Design. First Edition. Boston: Cengange Learning.

6. Gani, A.J.A. (2013). Dampak Implementasi Kebijakan Restrukturisasi Organisasi Pemerintah Daerah (Studi pada Pemerintah Kabupaten Tuban). Jurnal Administrasi Publik FIA. UB. Malang.

7. Gouillart, F. J., \& Kelly, J. N. (1995). Transforming the organization. New York: McGrawHill.

8. Ibrahim, I. (2018). Analisis Kebijakan Restrukturisasi Organisasi Perangkat Daerah Gorontalo. Jurnal BPPG-Humaniora, 2 (2): 32-42.

9. Köper, B. and Richter, G. (2014). Restructuring of organizations and potential implications for their staff. Harvard Business Press, Boston.

10. Landau, J. (1993). Organizational Change and Barries to Innovation: A case study in The Italian Public Sector. Journal Human Relation, 46 (12): 1411-1429. doi:10.1177/001872679304601203.

11. Miles, M.B. and Huberman, A.M. 2014. Qualitative Data Analysis: A Source Book of New Metdhods. Baverly Hills: Sage Publications, Inc.

12. Mintzberg, Henry. 1996. The Structuring of Organizations a Synthesis of the Research. Englewood Cliffs N.J.: Prentice-Hall, Inc. 
13. Obolensky, N. (1996). Practical Business Re-Enginering. Terjemahan oleh Soesanto Budidarmo. Jakarta: Elex Media Komputindo.

14. Osborne, D. and Gaebler. (1995). Reinventing Government: How the Entrepreneurial Spirit is Transforming the Public Sector. Terjemahan Abdul Rosyid. "Mewirausahakan Birokrasi". Jakarta: Pustaka Binaman Pressindo.

15. Peraturan Pemerintah Nomor 41 Tahun 2007 tentang Organisasi Perangkat Daerah (Lembaran Negara Republik Indonesia Tahun 2007 Nomor 89, Tambahan Lembaran Negara Republik Indonesia Nomor 4741).

16. Pfiffner, J. and Presthus, R.V. (1960). Public Administration. New York: The Ronald Press Company.

17. Potts, R. and LaMarsh, J. (2004), Managing for Success: Effecting change for optimum growth and maximum efficiency. London: Duncan Baird Publisher.

18. Savage, C. M. (1996). 5th Generation management: Co-creating through virtual enterprising dynamics, teaming and knowledge networking. New York: ButterworthHeineman.

19. Sedarmayanti. (2009). Reformasi Administrasi Publik: Reformasi Birokrasi, dan Kepemimpinan Masa Depan: Mewujudkan Pelayanan. Bandung: Refika Aditama.

20. Sudirman dan Widjanarko, T. (2004). "Akip dan Pengukuran Kinerja". Jakarta: LAN.

21. Supriyono, B. (2007). "Pembangunan Institusi Pemerintahan Daerah Dalam Penyediaan Prasarana Perkotaan di Kota Malang" Disertasi Doktor, Universitas Indonesia. Jakarta.

22. Suyono. (2002). "Implementasi Kebijakan Restrukturisasi Kelembagaan Pemerintah Daerah Guna Mendukung Otonomi Daerah di Kabupaten Probolinggo (Tesis).

23. Undang-Undang Nomor 25 Tahun 2004 tentang Sistem Perencanaan Pembangunan Nasional (Lembaran Negara Republik Indonesia Tahun 2004 Nomor 104, Tambahan Lembaran Negara Republik Indonesia Nomor 4421).

24. Undang-Undang Nomor 33 Tahun 2004 tentang Perimbangan Keuangan Antara Pemerintah Pusat dan Pemerintahan Daerah (Lembaran Negara Republik Indonesia Tahun 2004 Nomor 126, Tambahan Lembaran Negara Republik Indonesia Nomor 4438)

25. Undang-Undang Nomor 23 Tahun 2014 tentang Pemerintah Daerah. (Lembaran Negara Republik Indonesia Tahun 2014 Nomor 130, Tambahan Lembaran Negara Republik Indonesia Nomor 5049).

26. Wibowo. (2008). Manajemen Kinerja. Jakarta. Raja Grafindo Persada. 